\title{
Plant-soil interactions in global biodiversity hotspots
}

\author{
Antony van der Ent • Hans Lambers
}

Received: 21 January 2016 / Accepted: 10 May 2016/Published online: 18 May 2016

(C) Springer International Publishing Switzerland 2016

This Special Issue explores plant-soil interactions in global biodiversity hotspots and highlights the extent to which these interactions may play a role in explaining the megadiversity of these hotspots. On a global scale, biodiversity hotspots are mainly located where high relief (mountains) and high geodiversity (variety in geology and soils) intersect, especially in tropical and Mediterranean climate regions. Factors causing spatial heterogeneity of temperature and precipitation often further increase the number of plant species per unit area. Meta-analyses indicate about twenty global biodiversity hotspots with $>3000$ plant species per $10,000 \mathrm{~km}^{2}$ (Mutke and Barthlott 2005; Barthlott et al. 2007). The top five localities with $>5000$ species per $10,000 \mathrm{~km}^{2}$, covering just $0.2 \%$ of the Earth's land area surface, but harbouring $6.2 \%$ of total plant diversity, are: i) Costa Rica-Chocó; ii) Atlantic Brazil; iii) Tropical Eastern Andes; iv) Northern Borneo; and v) New Guinea (Barthlott et al. 2005). Although most biodiversity hotspots are in moist tropical regions, there are also regions with a Mediterranean climate that are extremely species-rich: the South African Cape (fynbos), California (chaparral) in the United States,

Responsible Editor: Rafael S. Oliveira.

A. van der Ent $(\bowtie)$

Centre for Mined Land Rehabilitation, Sustainable Minerals Institute, The University of Queensland, Brisbane, QLD 4072, Australia

e-mail: a.vanderent@uq.edu.au

H. Lambers

School of Plant Biology, University of Western Australia, Crawley, WA 6009, Australia and the sandplains (kwongkan) of south-western Australia. Some islands are also global centres of diversity and endemicity, notably New Caledonia, Madagascar and the islands of the Malesian archipelago.

Soil fertility has been posited as a key driver for plant diversification through resource competition to access limiting nutrients, and there is abundant evidence for increasing plant diversity with decreasing soil nutrient status, especially in the case of phosphorus (Huston 1979, 1980; Lambers et al. 2010; Blanck et al. 2011; Olde Venterink 2011; Pekin et al. 2012). The 'biogeochemical niche' hypothesis proposes that plants competing in the same habitat with co-existing plant species use essential elements differently (Garten 1978; Peñuelas et al. 2009, 2013; Sulpice et al. 2014; Chimphango et al. 2015; Lambers et al. 2015). Such resource partitioning relates to evolved efficiency in uptake, symbiotic relationships and specialised metabolic functioning, as well as opportunistic use of micro-scale habitat and soil chemical gradients. Different nutrientacquisition strategies as a consequence could promote niche differentiation and hence reduce competition for limiting resources (Fyllas et al. 2009). A recent study conducted in the kwongkan of south-western Australia showed, however, that variation in plant diversity is not explained by local resource heterogeneity/partitioning and soil fertility along a gradient, but rather determined by environmental filtering driven by decreasing phosphorus availability and soil acidification during long-term pedogenesis, and this highlights that long-term evolutionary processes shape present-day species pools (Laliberté et al. 2014).

An example in case of nutrient-limited soils are those derived from ultramafic geology, characterised by an 
unusual geochemistry with low calcium/magnesium quotients, limited phosphorus and potassium availability and concomitantly high concentrations of nickel (Van der Ent et al. 2016a). These soils can impose edaphic stresses that may favour the evolution of plant species by promoting divergence, as a result of the insular occurrence of these soils, ultimately leading to adapted specialistic plants and endemism (Whittaker 1954; Rajakaruna 2004; O'Dell and Rajakaruna 2011). In many hotspots, such as in California and New Caledonia, the presence of ultramafic soils contributes disproportionally to concentrating the local levels of plant diversity (Harrison et al. 2006; Isnard et al. 2016). This is reflected in this Special issue, with four articles focussing on ultramafic ecosystem in the biodiversity hotspots of New Caledonia, Northern Borneo and the Mediterranean Basin. Elsewhere, other types of geodiversity have also provided evolutionary forces driving plant diversification, for example in Brazil, in the rock outcrops of the Brazilian Atlantic Rainforest (do Carmo and Jacobi 2016) and in the campos rupestres (Silveira et al. (2016).

Patterns of biodiversity are highly scale-dependent, and particularly high levels of diversity often coincide with habitat patchiness and species turnover $(\beta-$ diversity) along gradients (Harrison and Inouye 2002). This is exemplified by the case of Mount Kinabalu in Northern Borneo, which has more than 5000 vascular plant species in less than $1200 \mathrm{~km}^{2}$ (Beaman 2005). A large-scale ecological study shows that within climatic zones on this mountain the distribution of plant species is linked to soil chemistry with stunted vegetation and elevational floristic compression on chemically-adverse ultramafic soils (van der Ent et al. 2016b). Where the effects of high-altitude and nutrient-poor soil combine in tropical rainforest, gymnosperms may compete with angiosperm trees facilitated through high insolation (Sawada et al. 2016). Elsewhere in Southeast Asia, on Hainan Island (China), a large-scale plot study by Jianga et al. (2016) emphasised the importance of soil and microclimatic factors for driving diversity in lowland and montane (semi-deciduous) forests. In the Brazilian Atlantic rainforest, outcrops of a different geological origin also enhance the plant megadiversity through promoting edaphic and topographic gradients, resulting in high $\alpha$ - and especially $\beta$-diversity (do Carmo and Jacobi 2016). In Brazil, such local fine-scale variation in soil nutrient and/or moisture availability influences radial growth of the dominant tree species, Dalbergia nigra (Pontara et al. 2016). However, ostensibly homogenous habitats, notably old climatically-buffered infertile landscapes (OCBILs), are also exceptionally species-rich, the fynbos of the Cape Floristic Region and the kwongkan of south-western Australia are famous examples (Allsopp et al. 2014; Lambers 2014), but campos rupestres fall in the same category (Silveira et al. 2016; Oliveira et al. 2015, 2016).

The role of cluster roots and functionally similar root structures and of root architecture in severely phosphorus-impoverished landscapes is explored in two articles focussing on Eucalyptus and a Proteaceae from Australia and Brazil, respectively. Experimental evidence shows that the root architecture and biomass allocation of Eucalyptus species reflects that of edaphic adaptations of specialised species, even when grown under common conditions (Hamer et al. 2016). This may have implications for the ability of edaphic specialists to acclimate to changes in their environment, especially climate change. Another edaphic root adaptation is the formation of cluster roots, which are generally associated with a burst of carboxylate exudation to enhance phosphorus uptake in phosphorus-limited environments (Shane and Lambers 2005). Cluster roots are best known from the sandplains of south-western Australia; their formation is suppressed at elevated phosphorus supply, in response to elevated leaf phosphorus concentration (Shane et al. 2003). However, studies with a Brazilian Proteaceae demonstrated that, unusually, cluster-root formation and foliar phosphorus concentration do not depend on the amount of phosphorus supplied under experimental conditions (de Britto et al. 2016). Root mycorrhizal associations are another adaptation of plants growing on nutrient-impoverished soils, and their effect on legume trees in French Guiana is the subject of the work presented by Brearley et al. (2016). Rhizobacterial communities were also investigated in an extreme microhabitat: the roots of nickelhyperaccumulating plants (Álvarez-López et al. 2016). The results of that study exhibit that even under toxic conditions the diversity of microbes associated with hyperaccumulating roots may be high with selective enrichment of nickel-tolerant bacteria. One especially intriguing example of edaphic specialisation is the evolution of carnivorous plants in the genus Nepenthes from the pitcher-plant family (Nepenthaceae). In the Old World this genus is known for its many narrow endemics, restricted to severely nutrient-limited soils, often on isolated mountain peaks and ultramafic outcrops 
(van der Ent et al. 2016c). The roles of climate, soils and vicariance in shaping the diversity and distribution of Nepenthes in Southeast Asia are reviewed in an article by Clarke and Moran (2016).

Perhaps the most extreme example of plant-soil interactions occurs on metalliferous soils (Baker et al. 2010). The copper-cobalt outcrops of the Katangan Province in the Democratic Republic of the Congo are the richest location for metallophytes (plants growing in metalliferous soils) in the world, with over 600 species described to date (Faucon et al. 2010; Ilunga et al. 2013). The levels of endemism are especially remarkable and illustrate how challenging soil conditions can favour the evolution of edaphic endemics (Faucon et al. 2016). These mineralised outcrops are, however, under enormous pressure from the mining industry, which extract the resources contained in this region. Several articles in this Special Issue stress concerns for continued existence of highly-diverse edaphic floras, due to resource extraction, climate change, and land clearing. Priority setting is necessary to respond to global biodiversity threats, and there have been concerted efforts to shortlist major biodiversity hotspots, defined as biogeographic regions with $>1500$ endemic vascular plant species and less than $30 \%$ of original primary habitat remaining (Myers et al. 2000). This ultimately led to a compilation of 35 hotspots that combined cover $17.3 \%$ of the global land surface but contain $44 \%$ of all known species of vascular plants and $77 \%$ of all endemic plant species (Myers 2003; Myers et al. 2000; Mittermeier et al. 2004, 2011; Williams et al. 2011). In many hotspots, the strong link with geodiversity, epitomised by the occurrence of (edaphic) endemics, makes the local diversity especially threatened by habitat destruction and disturbances, as specialised species may be unable to survive under other conditions (Jacobi et al. 2011). Another threat may arise from limited investment in sexual reproduction in some endangered plants that are adapted to phosphorus-impoverished conditions which makes them more vulnerable to extinction (Fujita et al. 2014).

\section{References}

Allsopp N, Colville JF, Verboom GA (eds) (2014) Fynbos: ecology, evolution, and conservation of a megadiverse region. Oxford University Press, Oxford ISBN: 9780199679584

Álvarez-López V, Prieto-Fernández Á, Becerra-Castro C, Monterroso C, Kidd PS (2016) Rhizobacterial communities associated with the flora of three serpentine outcrops of the Iberian Peninsula. Plant Soil. doi:10.1007/s11104-0152632-0

Baker AJM, Ernst WHO, Van der Ent A, Malaisse F, Ginocchio R (2010) Metallophytes: the unique biological resource, its ecology and conservational status in Europe, Central Africa and Latin America. In: Batty LC, Hallberg KB (eds) Ecology of industrial pollution, 1st edn. Cambridge University Press, Cambridge ISBN: 0521730384, pp. 7-40

Barthlott W, Mutke J, Rafiqpoor MD, Kier G, Kreft H (2005) Global centers of vascular plant diversity. Nova Acta Leopold NF 342:61-83

Barthlott W, Hostert A, Kier G, Küper W, Kreft H, Mutke J, Rafiqpoor MD, Sommer H (2007) Geographic patterns of vascular plant diversity at continental to global scales. Erdkunde 61:305-315. doi:10.3112/erdkunde.2007.04.01

Beaman JH (2005) Mount Kinabalu: hotspot of plant diversity in Borneo. Biol Skr 55:103-127

Blanck YL, Gowda J, Martensson LM, Sandberg J, Fransson AM (2011) Plant species richness in a natural Argentinean matorral shrub-land correlates negatively with levels of plant phosphorus. Plant Soil. doi:10.1007/s11104-010-0671-0

Brearley FQ, Elliott DR, Amaia Iribar-Pelozuela A, Sen R (2016) Arbuscular mycorrhizal community structure on co-existing tropical legume trees in French Guiana. Plant Soil. doi:10. 1007/s11104-016-2818-0

Chimphango SBM, Potgieter G, Cramer MD (2015) Differentiation of the biogeochemical niches of legumes and non-legumes in the Cape Floristic Region of South Africa. Plant Ecol 216:1583-1595. doi:10.1007/s11258015-0542-0

Clarke C, Moran JA (2016) Climate, soils and vicariance - their roles in shaping the diversity and distribution of Nepenthes in Southeast Asia. Plant Soil. doi:10.1007/s11104-015-2696-x

de Britto CP, Abrahão A, Viani RAG, et al. (2016) Cluster-root formation and carboxylate release in Euplassa cantareirae (Proteaceae) from a neotropical biodiversity hotspot. Plant Soil. doi:10.1007/s11104-015-2630-2

do Carmo FF, Jacobi CM (2016) Diversity and plant trait-soil relationships among rock outcrops in the Brazilian Atlantic rainforest. Plant Soil. doi:10.1007/s11104-015-2735-7

Faucon M-P, Meersseman A, Shutcha MN, Mahy G, Ngongo LM, Malaisse F, Meerts P (2010) Copper endemism in the Congolese flora: a database of copper affinity and conservational value of cuprophytes. Plant Ecol Evol 143:5-18. doi: 10.5091/plecevo.2010.411

Faucon M-P, Le Stradic S, Boisson S, Ilunga EI, Séleck M, Lange B, Delhaye G, Shutcha MN, Pourret O, Meerts P, Mahy G (2016) Implication of plant-soil relationships for conservation and restoration of copper-cobalt ecosystems. Plant Soil. doi:10.1007/s11104-015-2745-5

Fujita Y, Venterink HO, van Bodegom PM, et al. (2014) Low investment in sexual reproduction threatens plants adapted to phosphorus limitation. Nature 505:82-86. doi:10.1038/ nature 12733

Fyllas NM, Patiño S, Baker TR, Bielefeld Nardoto G, Martinelli LA, Quesada CA, Paiva R, Schwarz M, Horna V, Mercado LM, Santos A, Arroyo L, Jiménez EM, Luizão FJ, Neill DA, Silva N, Prieto A, Rudas A, Silviera M, Vieira ICG, LopezGonzalez G, Malhi Y, Phillips OL, Lloyd J (2009) Basinwide variations in foliar properties of Amazonian forest: 
phylogeny, soils and climate. Biogeosci Discuss 6(2):37073769. doi:10.5194/bg-6-2677-2009

Garten CT Jr (1978) Multivariate perspectives on the ecology of plant mineral element composition. Am Nat 112:533-544. doi: $10.1086 / 283295$

Hamer JJ, Veneklaas EJ, Renton M, Poot P (2016) Links between soil texture and root architecture of eucalyptus species may limit distribution ranges under future climates. Plant Soil. doi: 10.1007/s11104-015-2559-5

Harrison S, Inouye BD (2002) High $\beta$ diversity in the flora of Californian serpentine 'islands'. Biodivers Conserv 11:18691876. doi:10.1023/A:1020357904064

Harrison S, Safford HD, Grace JB, Viers JH, Davies KF (2006) Regional and local species richness in an insular environment: serpentine plants in California. Ecol Monogr 76:4156. doi:10.1890/05-0910

Huston MA (1979) A general hypothesis of species diversity. Am Nat 113:81-101. doi:10.1086/283366

Huston M (1980) Soil nutrients and tree species richness in Costa Rican forests. J Biogeogr 7:147. doi:10.2307/2844707

Ilunga E, Séleck M, Colinet G, Faucon M-P, Meerts P, Mahy G (2013) Small-scale diversity of plant communities and distribution of species niches on a copper rock outcrop in Upper Katanga, D.R. Congo. Plant Ecol Evol 146:173-182. doi:10. 5091/plecevo.2013.816

Isnard S, Jaffré T, L'Huillier L, Rigault F (2016) Current knowledge of ultramafic plants in the biodiversity hotspot of New Caledonia. Plant Soil. doi:10.1007/s11104-016-2910-5

Jacobi CM, do Carmo FF, de Campos IC (2011) Soaring extinction threats to endemic plants in Brazilian metal-rich regions. Ambio 40:540-543. doi:10.1007/s13280-011-0151-7

Jianga Y, Zang R, Letcherd SG, Ding Y, Huang Y, Lu X, Huang J, Liu W, Zhang Z (2016) Associations between plant composition/diversity and the abiotic environment across six vegetation types in a biodiversity hotspot of Hainan Island, China. Plant Soil. doi:10.1007/s11104-015-2723-y

Laliberté E, Zemunik G, Turner BL (2014) Environmental filtering explains variation in plant diversity along resource gradients. Science 345:1602-1605. doi:10.1126/science. 1256330

Lambers H (ed) (2014) Plant life on the sandplains in Southwest Australia. UWA Publishing, Crawley ISBN: 1742585647

Lambers H, Brundrett MC, Raven JA, Hopper SD (2010) Plant mineral nutrition in ancient landscapes: high plant species diversity on infertile soils is linked to functional diversity for nutritional strategies. Plant Soil 334:11-31. doi:10.1007/ s11104-010-0444-9

Lambers H, Finnegan PM, Jost R, Plaxton WC, Shane MW, Stitt M (2015) Phosphorus nutrition in Proteaceae and beyond. Nat Plants 1. doi:10.1038/nplants.2015.1109

Mittermeier RA, Robles Gil P, Hoffmann M, Pilgrim J, Brooks T, Goettsch Mittermeier C, Lamoreux J, Da Fonseca GAB (2004) Hotspots revisited: earth's biologically richest and most endangered terrestrial ecoregions. CEMEX, Agrupación Sierra Madre, SC

Mittermeier RA, Turner WR, Larsen FW, Brooks TM, Gascon C (2011) Global biodiversity conservation: the critical role of hotspots. In: Zachos E, Habel JC (eds) Biodiversity hotspots: distribution and protection of conservation priority areas. Springer, Berlin, pp. 3-22
Mutke J, Barthlott W (2005) Patterns of vascular plant diversity at continental to global scales. Biol Skr 55:521-531 ISBN 877304-304-4

Myers N (2003) Biodiversity hotspots revisited. Bioscience 53: 916. doi:10.1641/0006-3568(2003)053[0916:bhr]2.0.co;2

Myers N, Mittermeier RA, Mittermeier CG, da Fonseca GAB, Kent J (2000) Biodiversity hot spots for conservation priorities. Nature 403:853-858. doi:10.1038/35002501

O'Dell RE, Rajakaruna N (2011) Intraspecific variation, adaptation, and evolution. In: Harrison S, Rajakaruna N (eds) Serpentine: the evolution and ecology of a model system. University of California Press, Berkeley ISBN: 9780520268357,pp. 97-137

Olde Venterink H (2011) Does phosphorus limitation promote species-rich plant communities? Plant Soil 345:1-9. doi:10. 1007/s11104-011-0796-9

Oliveira RS, Galvão HC, De Campos MCR, Pearse SJ, Eller CB, Lambers $H$ (2015) Mineral nutrition of campos rupestres plant species on contrasting nutrient-impoverished soil types. New Phytologist 205(3):1183-1194

Oliveira RS, Abrahão A, Pereira C, Teodoro GS, Brum M, Alcantara S, Lambers H (2016) Ecophysiology of campos rupestres plants. In: Fernandes WG (ed) Ecology and conservation of mountaintop grasslands in Brazil. Springer International Publishing, Cham, pp. 227-272

Pekin BK, Boer MM, Wittkuhn RS, Macfarlane C, Grierson PF (2012) Plant diversity is linked to nutrient limitation of dominant species in a world biodiversity hotspot. J Veg Sci 23: 745-754. doi:10.1111/j.1654-1103.2012.01386.x

Peñuelas J, Sardans J, Llusia J, Owen SM, Carnicer J, Giambelluca TW, et al. (2009) Faster returns on "leaf economics" and different biogeochemical niche in invasive compared with native plant species. Glob Chang Biol 16(8): 2171-2185

Peñuelas J, Sardans J, Llusia J, Silva J, Owen SM, Bala-Ola B, Linatoc AC, Dalimin MN, Niinemets Ü (2013) Foliar chemistry and standing folivory of early and late-successional species in a Bornean rainforest. Plant Ecolog Divers 6(2): 245-256. doi:10.1080/17550874.2013.768713

Pontara V, Bueno ML, Garcia LE, Oliveira-Filho AT, Pennington TR, Burslem DFRP, Lemos-Filho JP (2016) Fine-scale variation in topography and seasonality determine radial growth of an endangered tree in Brazilian Atlantic forest. Plant Soil: 1-14. doi:10.1007/s11104-016-2795-3

Rajakaruna N (2004) The edaphic factor in the origin of plant species. Int Geol Rev 46:471-478. doi:10.2747/0020-6814. 46.5.471

Sawada Y, Aiba S-I, Seino T, Kitayama K (2016) Size structure, growth and regeneration of tropical conifers along a soil gradient related to altitude and geological substrates on Mount Kinabalu, Borneo. Plant Soil. doi:10.1007/s11104015-2722-Z

Shane MW, Lambers H (2005) Cluster roots: a curiosity in context. Plant Soil 274:101-125. doi:10.1007/s11104-004-2725-7

Shane MW, De Vos M, De Roock S, Lambers H (2003) Shoot P status regulates cluster-root growth and citrate exudation in Lupinus albus grown with a divided root system. Plant Cell Environ 26:265-273. doi:10.1046/j.1365-3040.2003.00957.x

Silveira FAO, Negreiros D, Barbosa NPU, et al. (2016) Ecology and evolution of plant diversity in the endangered campo rupestre: a neglected conservation priority. Plant Soil. doi:10. 1007/s11104-015-2637-8 
Sulpice R, Ishihara H, Schlereth A, Cawthray GR, Encke B, Giavalisco P, Ivakov A, Arrivault S, Jost R, Krohn N, Kuo J, Laliberté E, Pearse SJ, Raven JA, Scheible WR, Teste F, Veneklaas EJ, Stitt M, Lambers H (2014) Low levels of ribosomal RNA partly account for the very high photosynthetic phosphorus-use efficiency of Proteaceae species. Plant Cell Environ 37:1276-1298. doi:10.1111/pce. 12240

Van der Ent A, Jaffré T, L'Huillier L, Gibson N, Reeves RD (2016a) The flora of ultramafic soils in the Australia-Pacific region: state of knowledge and research priorities. Aust J Bot 63:173-190. doi:10.1071/BT15038

Van der Ent A, Erskine PD, Mulligan DR, Repin R, Karim R (2016b) Vegetation on ultramafic edaphic islands in Kinabalu
Park (Sabah, Malaysia) in relation to soil chemistry and altitude. Plant Soil. doi:10.1007/s11104-016-2859-4

Van der Ent A, Sumail S, Clarke C (2016c) Habitat differentiation of obligate ultramafic Nepenthes endemic to Mount Kinabalu and Mount Tambuyukon (Sabah, Malaysia). Plant Ecol 216: 789-807. doi:10.1007/s11258-015-0468-6

Whittaker RH (1954) The ecology of serpentine soils. I. Introduction. Ecology 35:258-259 URL: http://www.jstor. org/stable/1931126

Williams KJ, Ford A, Rosauer DF, De Silva N, Mittermeier R, Bruce C, Larsen FW, Margules C (2011) Forests of east Australia: the 35th biodiversity hotspot. In: Zachos FE, Habel JC (eds) Biodiversity hotspots. Springer Publishers, London, pp. 295-310 